\title{
Relative Water Content and Rooting of Subirrigated Stem Cuttings in Four Environments without Mist
}

\author{
William R. Graves ${ }^{1}$ and Hongyi Zhang \\ Department of Horticulture, Iowa State University, Ames, IA 50011-1100
}

Additional index words. propagation, water relations, temperature, irradiance, Dendranthema $\times$ grandiflorum, Fuchsia $\times$ hybrida

\begin{abstract}
Air temperature and photosynthetically active radiation $(P A R)$ effects on relative water content (RWC), rooting percentage, root count, and root mass of unmisted, subirrigated stem cuttings of two taxa were determined. Leaf $\mathrm{RWC}$ of 'Charm' chrysanthemum [Dendranthema $\times$ grandiflorum (Ramat.) Kitamura] decreased until roots initiated and then increased, was lower for cuttings at $23{ }^{\circ} \mathrm{C}$ photoperiod $/ 14{ }^{\circ} \mathrm{C}$ dark than for cuttings at $31{ }^{\circ} \mathrm{C}$ photoperiod $/ 22^{\circ} \mathrm{C}$ dark, and was lower at 193 than at $69 \mu \mathrm{mol} \cdot \mathrm{m}^{-2} \cdot \mathrm{s}^{-1} \mathrm{PAR}$. Neither temperature nor PAR affected leaf RWC of 'Dollar Princess' fuchsia (Fuchsia $\times$ hybrida Hort. ex Vilm.), which increased linearly before and after root initiation. Rooting percentage and root count were higher with photoperiods at $31^{\circ} \mathrm{C}$ than at $23^{\circ} \mathrm{C}$ for chrysanthemum after 7 days and for fuchsia after 10 days. Although all cuttings of both taxa had rooted after 14 days, root dry mass was higher with photoperiods at $31{ }^{\circ} \mathrm{C}$ than at $23{ }^{\circ} \mathrm{C}$ regardless of $P A R$ for fuchsia and at $69 \mu \mathrm{mol} \cdot \mathrm{m}^{-2} \cdot \mathrm{s}^{-1} P A R$ for chrysanthemum. Propagators wishing to use subirrigation instead of mist, fog, or enclosure can minimize the decline in leaf RWC before root initiation and increase the number and dry mass of roots of chrysanthemum by using $69 \mu \mathrm{mol} \cdot \mathrm{m}^{-2} \cdot \mathrm{s}^{-1} \mathrm{PAR}$ and a $31^{\circ} \mathrm{C}$ photoperiod $/ 22^{\circ} \mathrm{C}$ dark cycle. Root dry mass of fuchsia also can be increased by the use of high temperature, but differences in rooting were independent of changes in leaf RWC.
\end{abstract}

Optimal root development on leafy stem cuttings is promoted by minimizing water stress and maximizing photosynthesis during propagation (Davis, 1988). Although mist, fog, and enclosure are used to increase relative humidity (RH) and minimize water stress, subirrigating cuttings without providing supplemental humidification can result in excellent rooting. Use of subirrigation instead of mist, fog, or enclosure could reduce propagation costs, prevent leaching of nutrients from foliage (Blazich et al., 1983), lower water usage, improve sanitation, and prevent deterioration of the cuticle that precedes leaf damage after rooting (Wilkins et al., 1995). Zhang and Graves (1995) found that rooting percentages for 'Charm' chrysanthemum, coleus ( $\mathrm{Co}$ leus $\times$ hybridus Voss.), 'Franksred' red maple (Acer rubrum L.), and Japanese tree lilac [Syring a reticulata (Blume) Hara] were at least as high for cuttings subirrigated and not misted as for cuttings provided intermittent mist in greenhouses with $\approx 55 \% \mathrm{RH}$. Root dry mass of subirrigated cuttings exceeded that of misted cuttings for all taxa, except chrysanthemum, which also exhibited the most foliar wilting

Received for publication 16 Jan. 1996. Accepted for publication 21 Mar. 1996. Journal Paper no. J16671 of the Iowa Agriculture and Home Economics Experiment Station, Ames, Project no. 3229, and supported by Hatch Act and State of Iowa funds. We are grateful to Yoder Suppliers, Alva, Fla., for donation of plant material. The cost of publishing this paper was defrayed in part by the payment of page charges. Under postal regulations, this paper therefore must be hereby marked advertisement solely to indicate this fact.

${ }^{1}$ To whom reprint requests should be addressed. during photoperiods before root initiation (Zhang and Graves, 1995).

Cuttings held where high RH is not maintained might be particularly sensitive to temperature and photosynthetically active radiation $(P A R)$ because of effects on foliar heat loads and vapor pressure deficits between leaves and the atmosphere (Grange and Loach, 1983; Jarvis, 1981). Zhang and Graves (1995) speculated that foliar water stress was responsible for the reduced root dry mass of unmisted, subirrigated cuttings of chrysanthemum. Therefore, the objective of this research was to determine how leaf water content and rooting of unmisted, subirrigated stem cuttings of 'Charm' chrysanthemum and 'Dollar Princess' fuchsia are affected by two air temperature regimes imposed at each of two $P A R$. Low $P A R$ was used so that results with chrysanthemum could be related to those of Zhang and Graves (1995), and because the PAR at which net photosynthesis is saturated is lower for detached cuttings than for intact plants (Davis and Potter, 1981; Machida et al., 1977). Fuchsia was studied because its leaves did not wilt when stem cuttings were subirrigated but not misted during preliminary trials.

\section{Materials and Methods}

Terminal stem cuttings of 'Charm' chrysanthemum with a stem length of $5.6 \pm 0.2 \mathrm{~cm}$ were obtained from Yoder Suppliers (Alva, Fla.). Terminal stem cuttings of 'Dollar Princess' fuchsia, $6.6 \pm 0.3 \mathrm{~cm}$ long, were collected from stock plants grown in a greenhouse. Cut ends were dipped in tap water and then in Hormodin 1 (MSD-AGVET, Rahway,
N.J.) powder that contained indolebutyric acid at $1 \mathrm{~g} \cdot \mathrm{kg}^{-1}$. Cuttings of both taxa were inserted $2 \mathrm{~cm}$ deep in individual Solo Dixie plastic cups (Solo Cup Co., Urbana, Ill.) filled with coarse perlite (Lite Weight Products, Kansas City, Kan.) and irrigated to container capacity with tap water that contained Peters Excel All Purpose $21 \mathrm{~N}-2.2 \mathrm{P}-16.6 \mathrm{~K}$ Fertilizer (Scotts, Marietta, Ga.) with $\mathrm{N}$ at $1.8 \mathrm{~mol} \cdot \mathrm{m}^{-3}$. Cups had a volume of $266 \mathrm{~cm}^{3}$, a bottom diameter of 50 $\mathrm{mm}$, were $98 \mathrm{~mm}$ tall, and had a top diameter of $76 \mathrm{~mm}$. A hole $2 \mathrm{~cm}$ long $\times 5 \mathrm{~mm}$ wide cut in the side of each cup $5 \mathrm{~cm}$ from the bottom allowed a reservoir of solution to remain in the lowest $5 \mathrm{~cm}$ of the cups.

Cuttings were assigned to a $2 \times 2$ factorial of temperature and PAR treatments. Fortyeight cuttings of each taxon were placed randomly in each of two growth chambers. Air in one growth chamber was $31 \pm 1.5^{\circ} \mathrm{C}$ during daily 12 -h photoperiods and $22 \pm 1{ }^{\circ} \mathrm{C}$ during dark hours. Air in the other growth chamber was $23 \pm 1.5^{\circ} \mathrm{C}$ during daily 12 -h photoperiods and $14 \pm 1.5^{\circ} \mathrm{C}$ during dark hours. $\mathrm{RH}$ during the photoperiod was monitored by using Fisher thermo-hygro meters (Fisher, Pittsburgh). Trays of water were added to or removed from the chambers as needed to maintain similar RH in the chambers. Mean maximum and minimum $\mathrm{RH}$ during photoperiods in the chamber at lower temperatures was $72.8 \% \pm 1.2 \%$ and $58.1 \% \pm 2.7 \%$; mean maximum and minimum RH at higher temperatures was $73.4 \% \pm 3.9 \%$ and $60.3 \% \pm 3.9 \%$.

Within both growth chambers, six cuttings each of the two taxa were arranged randomly in each of eight replications. PAR was reduced to $69 \pm 5 \mu \mathrm{mol} \cdot \mathrm{m}^{-2} \cdot \mathrm{s}^{-1}$ for four randomly selected replications in both chambers by suspending pieces of polypropylene netting 30 $\mathrm{cm}$ over the cuttings. The unshaded replications received $193 \pm 9 \mu \mathrm{mol} \cdot \mathrm{m}^{-2} \cdot \mathrm{s}^{-1} P A R$. Coolwhite fluorescent and incandescent lamps provided $96 \%$ and $4 \%$ of the total $P A R$, respectively. Treatments were imposed for 14 days. Additional fertilizer solution was added to the top of the cups after 3, 7, and 11 days until solution drained from side holes.

The six individual cups of both taxa were considered samples within replications. A sample of both taxa from each replication was removed in the eighth hour of the photoperiod on days $0,1,3,5,7$, and 14 (chrysanthemum) and days $0,1,3,5,10$, and 14 (fuchsia) to measure relative water content (RWC) of the two most basipetal leaves (Castonguay and Markhart, 1991). Rooting percentage and the number of roots per cutting were determined for cuttings selected for RWC determinations on day 7 (chrysanthemum) or day 10 (fuchsia). Rooting percentage, shoot length, and shoot and root dry mass were determined for cuttings selected for RWC determinations on day 14. Dry mass of the leaves used to determine RWC on day 14 was included in the shoot dry mass.

The experiment was conducted four times, and assignment of temperature treatments to growth chambers was random for each experiment. Treatment means from each experiment were used as replicates for data analysis. Analy- 
sis of variance and regression were conducted by using SAS version 6.06 (SAS Inst., Cary, N.C.). Mean separation was performed by using Fisher's LSD at $P=0.05$. Values for percent rooting were transformed to the arcsin of the square root before means were separated.

\section{Results}

$\operatorname{PAR}(P>\mathrm{F}=0.0002)$ and temperature $(P$ $>\mathrm{F}=0.0129)$ affected leaf RWC of 'Charm' chrysanthemum. There was no interaction between these effects. Over all times and both PAR treatments, RWC of chrysanthemum was $71 \%$ for cuttings at $31^{\circ} \mathrm{C}$ during photoperiods and $65 \%$ for cuttings at $23{ }^{\circ} \mathrm{C}$ during photoperiods $(\mathrm{LSD}=5 \%)$. RWC of chrysanthemum was higher at 69 than at $193 \mu \mathrm{mol} \cdot \mathrm{m}^{-2} \cdot \mathrm{s}^{-1} P A R$, and RWC declined during the first 5 days but then increased regardless of $P A R$ (Fig. 1A). Neither $P A R$ nor temperature affected leaf RWC of 'Dollar Princess' fuchsia, which increased linearly from $91 \%$ to $95 \%$ over time (Fig. 1B).

More cuttings rooted and there were more roots per cutting with photoperiods at $31{ }^{\circ} \mathrm{C}$ than at $23^{\circ} \mathrm{C}$ for chrysanthemum after 7 days and for fuchsia after 10 days (Table 1). PAR had no effect on rooting percentage and root count. After 14 days, all cuttings of both taxa had rooted regardless of $P A R$ and temperature. There was a $P A R \times$ temperature interaction for the dry mass of roots of chrysanthemum after 14 days. Root dry mass was $150 \%$ higher with photoperiods at $31{ }^{\circ} \mathrm{C}$ than at $23{ }^{\circ} \mathrm{C}$ for cuttings provided $69 \mu \mathrm{mol} \cdot \mathrm{m}^{-2} \cdot \mathrm{s}^{-1} P A R$, but temperature did not affect root dry mass of chrysanthemum provided $193 \mu \mathrm{mol} \cdot \mathrm{m}^{-2} \cdot \mathrm{s}^{-1} P A R$ (Table 2). PAR did not affect root dry mass of fuchsia, and over both $P A R$ treatments, root dry mass at $31^{\circ} \mathrm{C}$ was $163 \%$ higher than for cuttings at $23^{\circ} \mathrm{C}$ (Table 2 ).

\section{Discussion}

The leaf RWC data and patterns of turgidity loss we observed suggest rooting stem cuttings by using subirrigation instead of mist, fog, or enclosure evokes greater leaf water deficit stress in 'Charm' chrysanthemum than in 'Dollar Princess' fuchsia. Leaves of chrysanthemum had $15 \%$ to $30 \%$ reductions in RWC (Fig. 1A) and lost turgidity during photoperiods during the first week. Although leaves under all conditions lost turgidity, those exposed to $31{ }^{\circ} \mathrm{C}$ during photoperiods at 69 $\mu \mathrm{mol} \cdot \mathrm{m}^{-2} \cdot \mathrm{s}^{-1}$ PAR maintained the highest RWC (Fig. 1A). Cuttings of chrysanthemum exposed to these conditions also produced more root mass than cuttings exposed to photoperiods at $23^{\circ} \mathrm{C}$ or to $193 \mu \mathrm{mol} \cdot \mathrm{m}^{-2} \cdot \mathrm{s}^{-1} \mathrm{PAR}$ (Table $2)$, which evoked relatively low leaf RWC. The association between low RWC of leaves and relatively low root mass suggests the rooting of subirrigated cuttings of chrysanthemum can be optimized by exposing cuttings to temperatures and amounts of $P A R$ that minimize leaf water deficits. The relatively high rooting percentage on day 7 of chrysanthemum at 31 ${ }^{\circ} \mathrm{C}$ during photoperiods with $69 \mu \mathrm{mol} \cdot \mathrm{m}^{-2} \cdot \mathrm{s}^{-1}$

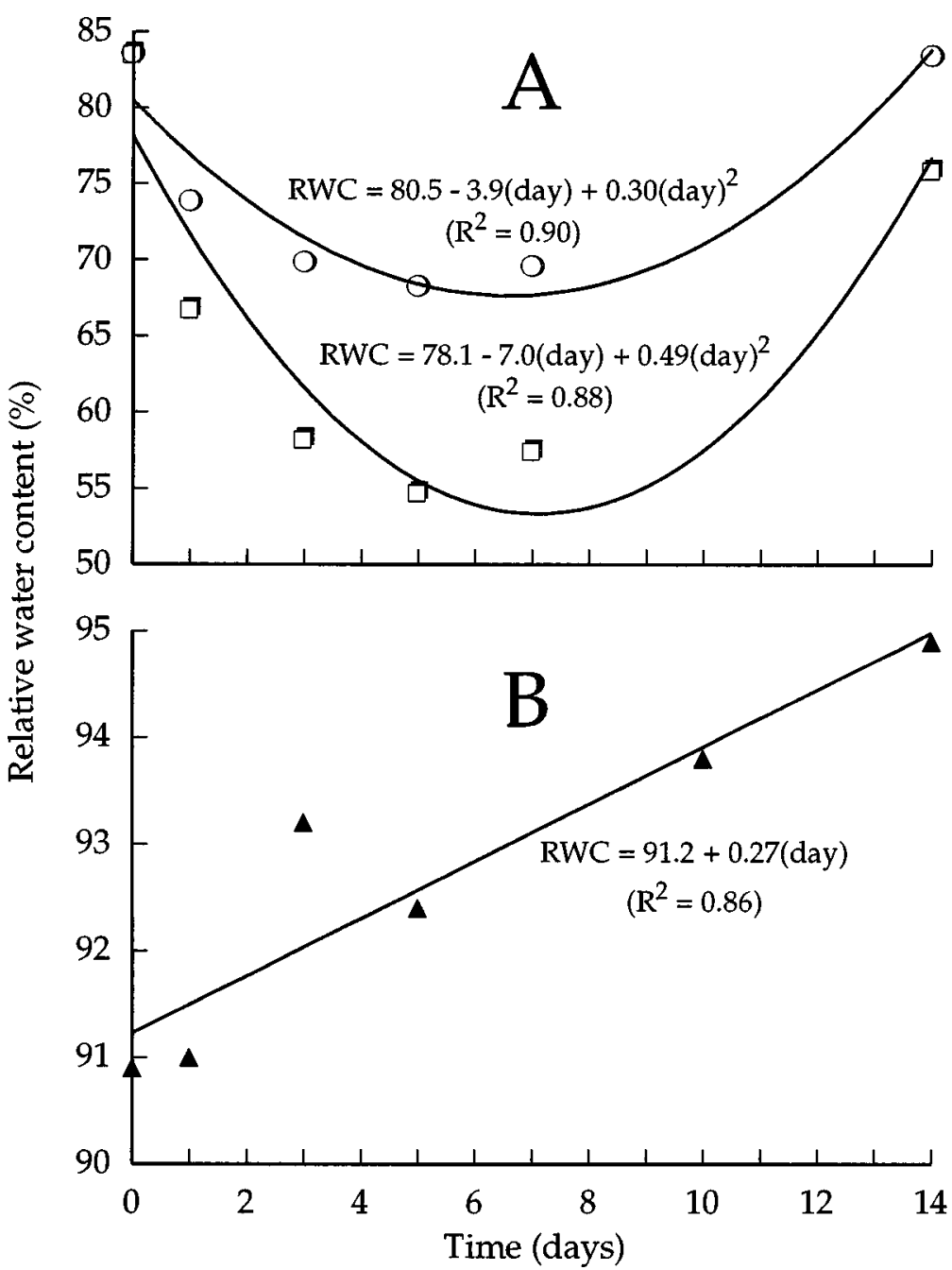

Fig. 1. Relative water content (RWC) of leaves of (A) 'Charm' chrysanthemum at 69 (— - ) and 193 $(-\square-) \mu \mathrm{mol} \cdot \mathrm{m}^{-2} \cdot \mathrm{s}^{-1} P A R$ and $(\mathbf{B})$ 'Dollar Princess' fuchsia over both $P A R$ treatments (- $\left.-\mathbf{\Delta}-\right)$ during propagation with subirrigation instead of mist. Each value is a mean from four replicate experiments over time. Data collected from cuttings at two air temperatures have been combined for presentation. Note difference in scale for RWC in (A) and (B).

Table 1. Rooting percentage and number of roots on subirrigated stem cuttings of 'Charm' chrysanthemum after 7 days and 'Dollar Princess' fuchsia after 10 days.

\begin{tabular}{lcrr}
\hline & Air temp & Rooting & No. \\
Taxon & during photoperiod $\left({ }^{\circ} \mathrm{C}\right)$ & percentage $^{\mathrm{z}, \mathrm{y}}$ & $1 \mathrm{~b}$ \\
\hline Chrysanthemum & 23 & $25 \mathrm{~b}^{\mathrm{x}}$ & $14 \mathrm{a}$ \\
& 31 & $91 \mathrm{a}$ & $0 \mathrm{~b}$ \\
Fuchsia & 23 & $0 \mathrm{~b}$ & $19 \mathrm{a}$ \\
& 31 & $100 \mathrm{a}$ & \\
\hline
\end{tabular}

${ }^{\mathrm{z}}$ Values are means of four replicate experiments conducted over time.

y Data were analyzed after transformation to the arcsin of the square root.

${ }^{x}$ Mean separation within taxa and columns by least significant difference test at $P \leq 0.05$.

$P A R$ (Table 1) suggests that the severity of leaf water deficits influenced root initiation rate as well as accrual of root mass. Other researchers have shown rooting percentages are reduced by treatments that intensify decreases in leaf water potential during propagation (Grange and Loach, 1984; Loach, 1977; Loach and Whalley, 1978).

In contrast to chrysanthemum, leaf blades of fuchsia did not wilt in any environment, and RWC of leaves increased linearly before and after root initiation (Fig. 1B). 'Charm' chrysanthemum and 'Dollar Princess' fuchsia were chosen for this research because they responded differently to subirrigation propagation during preliminary trials, but they may not be representative of other cultivars of these species. Mechanisms underlying the water status of subirrigated stem cuttings of various cultivars of chrysanthemum and fuchsia, including those we used, merit further study. The vapor pressure deficit between the cuttings and the atmosphere can be used to assess environmental effects on the force promoting water loss from the cuttings. Assuming $100 \% \mathrm{RH}$ in the leaf tissue, $65 \% \mathrm{RH}$ of the air, and $101.3 \mathrm{kPa}$ atmospheric pressure, the vapor pressure deficits during photoperiods at 23 and $31{ }^{\circ} \mathrm{C}$ were 
Table 2. Root dry mass of subirrigated stem cuttings of 'Charm' chrysanthemum and 'Dollar Princess' fuchsia exposed for 14 days to two amounts of photosynthetically active radiation $(P A R)$ during photoperiods at 23 and $31^{\circ} \mathrm{C}$.

\begin{tabular}{lrr}
\hline \hline & \multicolumn{2}{c}{ Root dry mass $(\mathrm{mg})^{\mathrm{z}}$} \\
\cline { 2 - 3 } Taxon and & \multicolumn{2}{c}{$\begin{array}{c}\text { Air temp during } \\
\text { photoperiod }\left({ }^{\circ} \mathrm{C}\right)\end{array}$} \\
\cline { 2 - 3 }$P A R\left(\mu \mathrm{mol} \cdot \mathrm{m}^{-2} \cdot \mathrm{s}^{-1}\right)$ & 23 & 31 \\
\hline Chrysanthemum & $24 \mathrm{~b}^{\mathrm{y}}$ & $60 \mathrm{a}$ \\
69 & $21 \mathrm{~b}$ & $24 \mathrm{~b}$ \\
193 & $8 \mathrm{~b}$ & $21 \mathrm{a}$ \\
Fuchsia $^{\mathrm{x}}$ & &
\end{tabular}

${ }^{z}$ Values are means of four replicate experiments conducted over time.

${ }^{\mathrm{y}}$ Mean separation within taxa by least significant difference test at $P \leq 0.05$.

${ }^{x} P A R$ had no effect on root dry mass, so data from both $P A R$ treatments were combined.

1.0 and $1.6 \mathrm{kPa}$, respectively (Weast, 1968). These estimates do not account for possible differences in the temperature of leaf tissue and the atmosphere caused by differences in $P A R$, transpirational cooling, or other determinants of foliar heat load. Yet, given the important effect of temperature on vapor pressure, it is likely that the relatively high leaf RWC and rooting of chrysanthemum after 7 days and rooting of fuchsia after 10 days (Table 1) were associated with a relatively high vapor pressure deficit. Direct metabolic effects of temperature, the higher absolute humidity at $31^{\circ} \mathrm{C}$ than at $23{ }^{\circ} \mathrm{C}$, or temperature-mediated differences in foliar diffusive resistance to water loss and in conductance of water through the cut stem (Ikeda and Suzaki, 1986) might explain the differences in how RWC changed over time (Fig. 1) and the favorable rooting with photoperiods at $31^{\circ} \mathrm{C}$.

Maximizing net photosynthesis without inducing excessive water stress is believed to improve rooting of leafy cuttings (Davis, 1988). Root dry mass of 'Dollar Princess' fuchsia was higher with photoperiods at $31^{\circ} \mathrm{C}$ than at $23^{\circ} \mathrm{C}$ regardless of $P A R$, and root dry mass of 'Charm' chrysanthemum was highest at $31^{\circ} \mathrm{C}$ with the lower $P A R$ treatment (Table 2). Temperature and $P A R$ might have influenced net photosynthesis by affecting stomatal aperture (Gay and Loach, 1977) or through nonstomatal effects (Farquhar and Sharkey, 1982). RWC data indicate that possible temperature effects on photosynthesis of fuchsia were not related to leaf water stress (Fig. 1). For chrysanthemum, rooting percentage and root number after 7 days (Table 1) and root dry mass after 14 days (Table 2) were highest for cuttings with the highest leaf RWC (Fig. 1). This is consistent with findings of Zhang and Graves (1995) and suggests root dry mass was influenced directly by water stress or by photosynthesis or other physiological processes that were affected by leaf water status.

This study demonstrates that subirrigation is a viable method for rooting stem cuttings of 'Charm' chrysanthemum and 'Dollar Princess' fuchsia. Propagators wishing to use subirrigation instead of mist, fog, or enclosure can minimize the decline in leaf RWC before root initiation and produce propagules with well-developed root systems by exposing cuttings of chrysanthemum to $69 \mu \mathrm{mol} \cdot \mathrm{m}^{-2} \cdot \mathrm{s}^{-1} P A R$ and $31^{\circ} \mathrm{C}$. Root dry mass of fuchsia also can be increased by $31^{\circ} \mathrm{C}$, but differences in rooting under the environmental conditions we used were independent of changes in leaf RWC.

\section{Literature Cited}

Blazich, F.A., R.D. Wright, and H.E. Schaffer. 1983. Mineral nutrient status of 'Convexa' holly cuttings during intermittent mist propagation as influenced by exogenous auxin application. $\mathrm{J}$. Amer. Soc. Hort. Sci. 108:425-429.

Castonguay, Y. and A.H. Markhart, III. 1991. Saturated rates of photosynthesis in water-stressed leaves of common bean and tepary bean. Crop Sci. 31:1605-1611.

Davis, T.D. 1988. Photosynthesis during adventitious rooting, p. 79-87. In: T.D. Davis, B.E. Haissig, and N. Sankhla (eds.). Adventitious root formation in cuttings. Dioscorides, Portland, Ore.
Davis, T.D. and J.R. Potter. 1981. Current photosynthate as a limiting factor in adventitious root formation on leafy pea cuttings. J. Amer. Soc. Hort. Sci. 106:278-282.

Farquhar, G.D. and T.D. Sharkey. 1982. Stomatal conductance and photosynthesis. Ann. Rev. Plant Physiol. 33:317-345.

Gay, A.P. and K. Loach. 1977. Leaf conductance changes on leafy cuttings of Cornus and Rhododendron during propagation. J. Hort. Sci. 52:509-516.

Grange, R.I. and K. Loach. 1983. Environmental factors affecting water loss from leafy cuttings in different propagation systems. J. Hort. Sci. $58: 1-7$.

Grange, R.I. and K. Loach. 1984. Comparative rooting of eighty-one species of leafy cuttings in open and polyethylene-enclosed systems. J. Hort. Sci. 59:15-22.

Ikeda, T. and T. Suzaki. 1986. Influence of hydraulic conductance of xylem on water status in cuttings. Can. J. For. Res. 16:98-102.

Jarvis, P.G. 1981. Stomatal conductance, gaseous exchange and transpiration, p. 175-204. In: J. Grace, E.D. Ford, and P.G. Jarvis (eds.). Plants and their atmospheric environment. Blackwell, Oxford, England.

Loach, K. 1977. Leaf water potential and the rooting of Rhododendron, Ceanothus thyrsiflorus and Hebe cuttings under mist and polyethylene. Physiol. Plant 40:191-197.

Loach, K. and D.N. Whalley. 1978. Water and carbohydrate relationships during the rooting of cuttings. Acta Hort. 79:161-168.

Machida, H., A. Ooshi, T. Hosoi, H. Komatsu, and F. Kamota. 1977. Studies on photosynthesis in cuttings during propagation. I. Changes in the rate of apparent photosynthesis in the cuttings of several ornamental plants after planting. J. Jpn. Soc. Hort. Sci. 46:274-282.

Weast, R.C. (ed.). 1968. CRC handbook of chemistry and physics. 49th ed. The Chemical Rubber Co., Cleveland.

Wilkins, L.C., W.R. Graves, and A.M. Townsend. 1995. Development of plants from single-node cuttings differs among cultivars of red maple and Freeman maple. HortScience 30:360-362.

Zhang, H. and W.R. Graves. 1995. Subirrigation to root stem cuttings: Comparison to intermittent mist and influence of fertilization. HortTechnology 5:265-268. 